\title{
The unfinished democratization of Europe
}

By Erik O. Eriksen

Paper to EUSA Conference 2007: Montreal

EUSA Tenth Biennial International Conference!

Montreal, Canada, May 17-May 19, 2007

Panel 10D

ARENA - Centre for European Studies at the University of Oslo

Arena, P.O. Box 1143, Blindern, N-0317, Oslo, Norway.

http://www.reconproject.eu

e.o.eriksen@arena.uio.no 


\begin{abstract}
There is a tension between democracy, which is limited to the nation-state, and human rights, which are universal and point to the ideal republic. The Charter of Fundamental Human Rights of the European Union is an important step in the process of institutionalising a framework of a cosmopolitan order where violations of human rights can be persecuted as criminal offences according to legal procedures. The principle of popular sovereignty is on its way to be transformed into a law for the citizens of the world. But as the process of Europeansation is tainted with juridification and executive dominance the EU is in need of democratization. The citizens have obtained rights but they have not been able to give these rights to themselves. The protracted Constitutionmaking process of the EU testifies to a promising yet unaccomplished mission of democratization.
\end{abstract}




\section{Introduction}

It was in Europe the modern system of states was invented and it is Europe that has come farthest in changing it. We witness a significant development of rights and law enforcement beyond the nation state. Processes of institution building at the European level are challenging the fundamental building blocs of democratic rule in Europe and constrain the will power of the states. Consider for example the sanctions imposed on Austria in 2000 by the fourteen other Member States for letting Haider's Freedom Party a rightwing, 'racist' party - into government. It was the Member States that decided to impose sanctions against Austria - in line with Article 7 (TEU). The EU has now amended this article to ensure that breaches of fundamental principles can be sanctioned. That a new order is underway is perhaps most clearly revealed in the initiative taken to make a Charter of Fundamental Rights of the European Union.

It is the sovereignty of the modern state as laid down in the Westphalian order in 1648 that is at stake with the institutionalization of human rights beyond the nation state. With this Treaty, the rulers' external sovereignty was safeguarded and the international order became founded on the principles of co-existence and non-interference among sovereign states. Prohibition of violence against sovereign states was here prioritized over the protection of human rights. This principle can not prohibit genocide or other crimes against humanity. It is a principle that has protected the most odious regimes. To illustrate, it was only when Hitler-Germany attacked Poland that World War II broke out, not when the persecution of Jews started. This also indicates the limitations of nationally founded and confined democracy. While human rights are universal and refer to humanity as such, democracy refers to a particular community of legal consociates who come together to make binding collective decisions. The validity of the laws is derived from the legislative processes of a sovereign community. The propensity to adopt rights, then, depends on the quality of the political process in a particular community. But a particular state may fail to respect the rights and liberties of their citizens as well as other states' legitimate interests. Even though the contradiction between rights and democracy is, in principle, a false one, since there can be no democracy without the protection of individual rights, and since rights are not valid unless they have been democratically enacted; in practical terms there is a contradiction as democracy is only institutionalised 
at the level of the nation state - as 'a national community of faith' that autonomously govern itself. Democracy depends on particular states with very different political cultures, which are geared toward self-maintenance: the primary responsibility of the decision-makers is their own constituency. Hence, democracies may be illiberal. To resolve this tension cosmopolitan democracy where actors see themselves as citizens of the world and not merely of their countries is required.

In this article I ask whether the rights development at the European level, in the $\mathrm{EU}$, can close the gap between abstract human rights and the need for democratic legitimation. In Europe, the states of a conflict-ridden continent have domesticated international relations among themselves through a process with strong traits of juridification and executive dominance. The lingering question is whether the ensuing order can be democratic, which I examine with regard to the recent development of bringing democracy to bear on the EU. I conclude that the present constitutinalization process - the process of forging a Constitutional Treaty - is testimony of an unfinished process of democratization.

\section{Juridification and Executive dominance}

In the last decades we have witnessed a significant development of rights and law enforcement beyond the nation state that bypasses democratic control. Juridification denotes the expansion of legal norms and the accompanying system of adjudication to new domains of social life. It depicts law's expansion and differentiation as well as increased conflict resolution through legal means. ${ }^{1}$ It implies the imposition of a cooperative scheme upon others who cannot influence or revise the terms. ${ }^{2}$ Even though the development of the European community is a prime example of juridification beyond the nation state as citizens are being subjected to regulations stemming from Community law-making and intergovernmental proceedings, the problem it is not confined to Europe.

Regulatory institutions such as the WTO, the World Bank and the IMF impose a scheme of global economic cooperation on the basis of inter-state bargaining. However, there is also an increasing amount of judicial procedures at the international level set up to adjudicate in disputes over breaches of international law. "The diplomatic dispute settlement procedures under GATT, for instance have been replaced by a judicial dispute 
settlement mechanism under the WTO, which is authorized to convict, and if necessary punish, states that do not fulfil their commitments." ${ }^{3}$ We are witnessing the expansion of rule of law principle internationally complementing the domestic one, in areas such as international trade, security, labour, and environmental law. ${ }^{4}$

Similarly, human rights are institutionalised in international courts, in tribunals and increasingly also in politico-judicial bodies over and above the state that control resources for enforcing norm compliance. Examples are the rights embedded in the UN system, the international criminal tribunals for Rwanda and the former Yugoslavia, The Hague Court of Justice, The International Criminal Court, and the European Court of Justice. European states have incorporated 'The European Convention for the Protection of Human Rights and Fundamental Freedoms' and many of its protocols into their domestic legal systems. Thus legal developments over the last century have been remarkable and one of their main thrusts has been to protect human rights. Today, almost nobody can be treated as a stranger devoid of rights as legal entitlements are being entrenched in power wielding systems of action as well as in the actual policies pursued. There are no lawless areas left. ${ }^{5}$ Aggressors can be tried for crimes against humanity, and offensive wars are criminalized: Sometimes human rights protection trumps state sovereignty. The NATO war against Serbia in 1999 to protect an innocent population was formally illegal according to the UN Charter, but was declared legitimate by the Independent International Commission on Kosovo 2000.

Today, thus, for (at least some) states to be recognized as sovereign they have to respect basic civil and political rights. In principle, then, only a democratic state is a sovereign state and in such a state the majority can not suppress minorities. Moreover, as states have become increasingly interdependent and intertwined - as they have to cooperate in order to realize their interests - the parameters of power politics have changed. ${ }^{6}$ Hence the supreme principle of the state is no longer merely survival - salus populi suprema lex est. The very concept of sovereignty has changed, from denoting the supreme legal authority of the state to uphold the law within a certain territory and being independent from any external authority ${ }^{7}$, to one that subject state power to higher order principles. A UN panel writes: 
"In signing the Charter of the United Nations, States not only benefit from the privileges of sovereignty but also accept its responsibilities. Whatever perceptions have prevailed when the Westphalian system first gave rise to the notion of State sovereignty, today it clearly carries with it the obligation of a state to protect the welfare of its own peoples and meet its obligations to the wider international community."8

However positive by moral standards such a development is, it does not harmonize with the democratic idea that the people should be making the laws they are to obey. At the international arena, human rights are not democratically enacted. The new situation is marked by lack of democratic accountability, by juridification, technocratic governance and executive dominance. Juridification denotes that the citizens have obtained rights and can sue the authorities but they have not been able to give these rights to themselves. Even slaves and children enjoy rights. The positivisation of human rights is in need of democratization as there should be no humanitarization without representation.

The principle of democracy can be pinned down to two basic criteria: congruence and accountability. By congruence is meant the basic democratic principle that those affected by laws should also be authorized to make them. Accountability designates that the decision-makers can be held responsible by the citizenry and that, in the last resort, it is possible to dismiss incompetent rulers. Thus, in order for a polity to be democratically legitimate, it must, at a minimum, be organized in such a way that there is free access to the public realm, that governmental positions are open to all, that those who govern are appointed by election at regular intervals and their actions subjected to public scrutiny and judicial review. These principles are threatened by today's executive prominence, which denotes the net empowerment of the executive branch of states at the expense of parliamentary involvement and popular control. This applies when legislative assemblies and the general public are unable to put decision-makers to account. The inscrutability of decision makers at the international level due to lack of transparency exempt the executives of justificatory requirements and gives them an advantage in terms of information, which they can make use of in a technocratic way.

Today, citizens' interests are affected by processes of denationalization and globalization in ways and by bodies which are difficult to hold responsible via the ballot 
box. ${ }^{9}$ There is no longer overlap between decision-making participants and affected parties. Denationalisation shatters the two symmetries necessary for effective participation, first between the citizens and the decision-makers that ' $\ldots$ they are to hold to account, and secondly between the "output" (decisions, policies and so on) of decisionmakers and their constituents'. ${ }^{10}$ Without input congruence, participation in making the decisions that affect one, there can be no self-determination; and without output congruence, without overlap between the polity and the territory it controls, there can be no effective participation.

In a 'globalized', denationalized world the requirements of legitimacy and of efficiency, of input and output congruence, no longer coincide. Those who can be kept accountable have little control over the factors affecting peoples' lives, and those who have the decisive power are beyond democratic reach. The quest for post-national democracy then is due to the problem of handling juridification beyond the nation state, and it is a problem that stems from the problem of institutionalizing human rights correctly. As it is impossible to be fully democratic within a non-democratic world order, what is needed at the international level is not merely an intergovernmental organization that ensures observance of peace and human rights but rather a supranational body able to adjudicate in the name of all: an authoritative third party that acts as an mediator, arbitrator and judge. ${ }^{11}$ This requires a union of states bound by a constitution and not just a "permanent congress of states" - such as the League of Nations - as Kant foresaw; because "(J)just how the permanence of this union, on which "civilized" resolution of international conflict depends, can be guaranteed without the legally binding character of an institution analogous to a state constitution Kant never explains". ${ }^{12}$ The point is then barely that peace is only feasible among democratic states, but moreover that the union of states must itself be democratic in one form or the other. This is the background for the need of democratic orders over and above the nation state - the need for a legislative entity, which can give and change norms at the international level, of which the EU is the most prominent representative.

Polity-building beyond the nation state 
The EU has sustained a rapid expansion of political regulation in Europe and has over a period of fifty years transformed the political landscape in a profound manner. Integration has deepened as a wide range of new policy fields have been subjected to integrated action and collective decision-making. This has taken place not only with regard to trade, monetary and business regulation, fishing and agriculture but also with regard to foodstuff production, gene- and bio-technology, labor rights, environmental protection, culture, tourism, immigration, police and home affairs and now also with regard to a common foreign and security policy. The EU has succeeded in entrenching peace and it has established a Single Market, a Monetary Union - the Euro - a European citizenship and a (not ratified) Constitutional Treaty (CT). Even though the powers of the Union in many policy areas - such as social and tax policy - are severely restricted, a significant amount of laws and amendments in the nation states stem from the binding EU decisions, directives and regulations. The EU appears to have reached a stable political form based on a material constitution.

It has also widened and has successfully managed to include new members. The prospect of membership has made a huge contribution to regional stability, prosperity and has proved to be a very effective instrument for advancing democracy, rule of law and security. All applicant states have to incorporate the acquis communautaire - the body of EU's legal norms - and the accession criteria for membership included democracy and human rights in addition to administrative and economic ones. There has been a fundamental domestic change in response to EU rules and regulations. ${ }^{13}$

The EU at present consists of 27 member states and wields influence over states and citizens through such supranational institutions as the Commission, the European Court of Justice (ECJ), the Parliament (the EP) as well as through the intergovernmental Council - the most powerful body. The present state of affairs is due to a protracted process of integration. Since its inception the basis for cooperation has deepened and broadened, as reflected in the founding Treaties: from the Paris (1951) and Rome (1957) Treaties, through the Single European Act (1986), Maastricht (1992), Amsterdam (1997), Nice (2000), up to the Laeken declaration (2001) and the present-day work on forging a Constitutional Treaty (2002-2005). The supranational character of the legal structure of the EU started with the acceptance of a constitutional reading of the founding treaties, 
already in the 1950s, and explicitly in the 1960s, ${ }^{14}$ which transformed the EC from an international regime into a quasi-federal legal system based on the precepts of higher law-constitutionalism. This was synthetised by the European Court of Justice in the combined doctrines of direct effect (which affirms the full legal character, under certain conditions, of EC norms- first explicated in relation to Treaty provisions, later said to apply also to directives in the 1970s- and consequently implies that such norms might grant rights to European citizens qua Europeans) and supremacy of Union law (first explicated by the ECJ in 1964, and which states that national norms must give way to Community ones if an irreducible conflict arises within the scope of application of the Treaties). This has been coupled with the growth of the number of EU provisions and Court rulings, where the Court acts as a trustee of the Treaty and not as an agent of the member states.

The net upshot is that the requisite third party, in the form of an arbitrator but not in the form of a democratic legislative entity, has been established in Europe. (However, since 1995 the dispute-settlement mechanism of WTO has, as mentioned, also become independent of the contracting parties). What started out as piecemeal problem-solving for the member states - underpinned by the peace motive - has ended up in a supranational order subjecting the constituent parts to collectively binding decisions. The unbridled sovereigns authorized by the Westphalian order are now brought under the rule of a supra-national polity which disposes of an authoritative dispute resolution mechanism.

\section{Direct legitimacy}

Integration started with the institutionalization of a 'High Authority'- the Commission with some regulatory competence as a third party distinct from the contracting parties. ${ }^{15}$ However, the legitimacy of the EU was still derived from the member states; it was initially indirect, and, like any international organization, depending on its ability to produce outcomes. But today the democratic legitimacy of the member states cannot be established independently of the EU because they have become so deeply enmeshed that the pattern of legitimate authority in the states has been transformed. 
The EU is clearly something less than a federation but more than an international organization, a club, a 'Zweckbundnis' (Verband), regime or a confederation where the member states are the contracting parties. To the latter democratic criteria do not apply as it is the states not the citizens that make up the 'constituencies'; states are the sole sources of legitimacy and they act internationally on indirect and delegated powers on governance functions. Here, 'constitutions' are contracts as 'the pouvoir constituant' is structured as a juridical relationship between separate parties: a 'gentlemen's agreement' presupposing individual membership and sovereignty and where the signatories represent individual modalities of government, rather than a social pact among the citizens. Contractual based orders do not put up normative criteria of political legitimacy. ${ }^{16}$

In contrast to such orders the EU has become a polity that subscribes to democracy and human rights as legitimating criteria. It also disposes of an organized capacity to act - to make collectively binding decisions. EU decisions impinge on national priorities, influence the domestic allocation of resources and constrain the sovereignty and autonomy of the states. The EU performs functions that affect interests and identities all over Europe. In fact, the EU, which is a creature of the member states, has contributed to transform them, either directly or through unleashing processes of mutual learning and adaptation. The identity as well as the statehood of European states stem from their European-ness as national law has become entangled with EU law practice to the degree that the states are no longer merely 'nation states'. The collective self-conception of nation states has changed as they have become 'Member States' with rights and duties so that they can not serve as the source of their own legitimacy independently of the EU. Their legal identity has been Europeanized.

Union transactions are thus not merely functional problem-solving - they have turned 'political'. The presence of market-correcting or positive integration measures, such as certain redistributive schemes and means of standard-setting; the increased use of qualified majority voting testify to the EU as a system of dominance revolving around more than the 'low politics' or politics of the lowest common denominator. The European integration project, as many have pointed out, cannot be understood simply as a win-win situation, nor is this project merely about solving the perceived problems of the member states in line with the Pareto criterion. ${ }^{17}$ 
However, the EU has not only embraced democratic standards it has also taken measures to rectify the democratic deficiencies. This has happened through a decadeslong process in which EU institutions, notably the ECJ and the EP, member state governments and parliaments, social movements and popular pressure, have moved the EU into a post-national polity aspiring to direct legitimacy: the power wielding institutions should be authorized by the people and be accountable to the affected parties directly. This is seen first of all in the Charter of Fundamental Rights, which is the most explicit commitment as of yet to a full blown political union founded on democracy, rule of law and human rights - a rights-based citizens' Union. ${ }^{18}$ It was drafted by a political body, which referred to itself as a Convention, set up to consolidate the fundamental rights to be protected by the EU (based on the existing acquis communitaire) and it managed to work without major difficulties and produce a consensual result. ${ }^{19}$ The Convention method is based on broad participation - a majority of the members were parliamentarians who acted on an open mandate - on public debate, on procedures for deliberation rather than decision-making through crude bargaining at Intergovernmental Conferences (IGCs), which is the usual way of making Treaty changes.

\section{Chartering Europe}

At the December 2000 Summit in Nice, the Charter was solemnly proclaimed and was picked up by the Laeken process and the Convention on the Future of Europe, which started its work in February 2002 and completed its activities in June/July 2003. ${ }^{20}$ This so-called Constitutional Convention succeeded in forging agreement on a single constitutional proposal 2003 - a draft Constitutional Treaty (CT), which the IGC accepted (with some minor amendments) in June 2004, (but which was rejected in two referendums in France and Nederland spring 2005). The CT incorporated the Charter of Fundamental rights into the Constitution. All articles on the rights of EU citizens in the Treaty of the Union have now been collected in one document of 54 articles, inspired by the 'The European Convention for the Protection of Human Rights and Fundamental Freedoms' (ECHR) (without replacing it), the Social Charters adopted by the Council of Europe and by the Community and the case-law of the European Court of Justice (ECJ). 
The Charter contains provisions on civil, political, social and economic rights. Put together, these are intended to ensure the dignity of the person, to safeguard essential freedoms, to provide a European citizenship, to ensure equality, to foster solidarity, and to provide for justice. The number and range of rights that are listed are comprehensive. The Charter enumerates several 'rights to solidarity' - hence, the protection of social rights is now included as a basic commitment for the Union - even though the realisation of these is not within the actual competence of the Union. They nevertheless constitute vital reasons to except market freedoms in the pursuit of social and redistributive goals. ${ }^{21}$ Thus, the EU can no longer be seen merely as a market project, if it ever could. In addition to provisions which most charters and bills of rights hold and which pertain to such clauses as the right to life, security, dignity there are numerous articles that seek to respond directly to contemporary issues and challenges (including abolition of death penalty, prohibition of cloning, protection of intellectual property).

Even though the Charter is not as yet legally binding, '(i)n practice, (...) the legal effect of the solemn proclamation of the Charter of Fundamental Rights of the European Union will tend to be similar to that of its insertion into the Treaties on which the Union is founded'. ${ }^{22}$ The Charter reflects the well established rights and value-basis of the Community. ${ }^{23}$ Moreover, since it consolidates existing positive law in one sense it may be seen as already binding. It has also increased its legal bite over a short period of time as the Court of first Instance has invoked the Charter as legal authority in several judgments. ${ }^{24}$ It has been referred to by institutional actors like the European Ombudsman and the Commission, and most Advocates-General of the European Court of Justice have also made use of provisions of the Charter as legal grounds of their opinions. AG Mischo went further and commented that:

'I know that the Charter is not legally binding, but it is worthwhile referring to it given that it constitutes the expression, at the highest level, of a democratically established political consensus on what must today be considered as the catalogue of fundamental rights guaranteed by the Community legal order. 25

Bills of rights empower the judges to protect liberty and hinder that democracy by means of majority vote crushes individual rights. It is the protection of individual rights and the constraints on state autonomy that marks the normative basis of the European 
constitutional development. ${ }^{26}$ This is reflected in the early decisions of the ECJ on direct effect and supremacy, in the conditionality clause (all aid and trade agreements are conditional on respect for human rights), in gender-equality and citizenship-rights policies, a process culminating with the Charter of Fundamental Rights; whose preamble states that “.... [T]the Union is founded on the indivisible, universal values of human dignity, freedom, equality and solidarity; it is based on the principles of democracy and the rule of law. It places the individual at the heart of its activities, by establishing the citizenship of the Union and by creating an area of freedom, security and justice.”

The individual is in the process of being liberated from the confines of the nation state as institutions above the nation-state are now in place with the competence to constrain the internal willpower of the state, i.e., the power exerted over its citizens. By this, international law is pushed beyond the limitations of the Charter of the United Nations, which on its behalf prohibits violence, and thus aggression against other states, but forbids the intervention in the internal affairs of a state (Article 2.7). A true republic certainly depends on bodies above the nation state that citizens can appeal to when their rights are threatened, but can such bodies be democratic? This is a question much neglected in the peace-through-law-movement spearheaded by Hans Kelsen. ${ }^{27}$

\section{Re-democratization}

In Europe the EU testifies to political initiatives that have resulted in supra-national institutions, which has shown a remarkable and unprecedented capacity to take on new collective measures and deepen integration. But, as I already claimed supra, this process of Europeansation is tainted with juridification and executive dominance. It is a process that has sapped parliamentary sovereignty at the member state level, and the question is whether democracy at the European level can compensate for this.

The ongoing process of rights' entrenchment in the $\mathrm{EU}$ comes close to a constitutionalizing one. From a cosmopolitan point of view such a development is important as it contributes to establish democratically controlled institutions at the regional level to cope with unattended problems. State and world citizenship form a continuum as people increasingly are affected by supranational powers. The EU can usefully be conceived of as an intermediate institution for grappling with exigencies 
connected to globalization, and thus is an interesting experiment in post-national regulation. The EU is an entity with strong supranational elements equipped with an organized capacity to act and it has now undertaken steps to reduce the democratic deficit.

The method adopted in 1999 by the Union for establishing the Charter offered a blueprint for an alternative mode of Treaty change which, after the Nice fiasco, became the role model for the so-called Laeken Convention of 2002-2003. Its membership was modeled on the Charter Convention, with a majority of parliamentarians. 46 out of 66 voting members, and 26 out of 39 from the candidate countries were parliamentarians. Its mandate was broader, its working method included working groups, and the applicant states had a number of representatives present, as active, participating, observers. Also this Convention had a distinctive deliberative mark, as opposed to the hitherto closed, secretive and executive-driven intergovernmental mode of treaty change. ${ }^{28}$ It succeeded in establishing a draft Constitutional Treaty (CT) which was signed by the Council 29 October 2004, and which contains measures aimed at mending the EU's legitimacy gap. This includes, in addition to the mentioned incorporation of the Charter of Fundamental Rights, the strengthening of the EP and of the national parliaments, the right to initiate a legislative proposal, the generalization of co-decision and qualified majority voting as decision-making procedures. Further, the CT adopts a constitutional language for legislation as it changes from the terminology of regulations and directives to laws and frameworks law corresponding to national practice (Article I-33). ${ }^{29}$ It depicts the EU as a supranational polity based on a dual principle of legitimation: It is both a Union of states and of citizens. The CT has been ratified by 13 states, but were rejected in two referenda - in France and Nederland June 2005 - and in July the European leaders resolved that there should be a 'reflection break' and postponed the time for the final ratification.

Neither the Charter Convention nor the Laeken Convention did have a satisfactory popular mandate and is thus problematic in democratic terms. ${ }^{30}$ But the Charter consolidates in a synthetic fashion the acquis communitaire on the protection of fundamental rights, and as such, its legitimacy is grounded on the constitutional traditions common to the Member States, whose democratic credentials are beyond doubt. Moreover, as most of those participating in the consolidation exercise were parliamentarians, the concrete text of the Charter can claim a democratic legitimacy 
(arguably) superior to Treaty making at IGCs. From a democratic point of view, law made through open deliberation by representatives fare better than one based on judicial activism and closed-door inter-state bargaining. However, even though democracy is internally related to rights - as there is no democracy without the protection of the fundamental rights of the individual - it is only through a democratic process of law enactment that we can know which rights are right, and how they should be delineated. It takes public deliberation to justify rights as democracy requires membership and participation in the very structures that affect individual interests. This is why the two aforementioned processes were unsatisfactory from a democratic point of view. On the other hand, democracy always entails undemocratic stipulations in the first place: it presupposes elements - in particular a demos and some rights - that are not subject to democratic decision-making.

\section{Post-national democracy}

What is new and interesting about the EU is its alleged democratic features even though the integration process has mainly taken place through law. The EU has become a more democratic institution because members of the Parliament are directly elected by citizens in the member states, (and the use of QMV has eroded the ability of individual countries to hold up new legislation). The ECJ has been a driving force in the political development of the EU and has independently strengthened the role of the European Parliament (EP). It has subjected the EP's decisions to substantive judicial review and thus has strengthened and authorized the view of it as an autonomous political body within the Union. Initially the EP was a consultative body - a talk shop - with very limited powers and made up foremost of representatives of national parliaments. Over time, and in particular after the introduction of direct election of MEPs in 1979, its decision-making powers have grown. ${ }^{31}$ The EP increased its status and power with the Single European Act, which marked a watershed as the cooperation procedure was introduced, then reinforced by the Maastricht and Amsterdam Treaty, which transformed the EP from a secondary institution to an important legislative actor. ${ }^{32}$ It has now achieved co-decision making power with the Council in many areas and is increasingly curtailing the power of the Commission. Despite the fact that the EP is not an agenda setter - this is the 
prerogative of the Commission - and its power is severely restricted compared to the powers of national parliaments it has changed from being a Parliament in the name to act like one.

The Constitutional Convention to a large degree embraced the parliamentary model of democratic legitimacy. It is the parliamentarian form of democracy - at the national and European level - that has carried the day in the reform process. Bluntly, democratizing the Union means parliamentarization. Now, this may be puzzling and indeed imply a technocratic 'overstretch of democratic resources'. As there is no European people - no demos - full parliamentarization of the EU is not possible according to many analysts. ${ }^{33}$ The constitution-making subject is missing according to the no-demos thesis' proponents. ${ }^{34}$ Without a collective identity symbolized by a people, there can be no authority conferred upon a government to rule in the name of all. Such make up the so-called non-majoritarian sources of legitimacy - or the socio-cultural substrate - that makes collective decision making possible. Majority rule rests upon allegiance and a notion of solidarity that is only conceivable in terms the symbolic establishment of a demos - a people - founded on a sense of unity and allegiance. This is held to be a precondition for a democratic sovereign capable of collective decisionmaking; for the outvoted minority to abide by the law, for the willingness of the citizens to pay for the misfortune of their compatriots. Such a solidaristic substrate is required for the formation of a collective identity strong enough to ensure that the compatriots not only see themselves as members of a community based on liberty but also as one based on equality and solidarity. ${ }^{35}$ Solidarity is, however, both the pre-requisite for deliberation and collective decision making and a result of such. From a discourse-theoretical point of view the question is not merely how much such commonality exists, but also how it can be brought about in trust fostering institutions - in inclusive publics of different kinds. ${ }^{36}$

As the EU is neither a state nor remotely a nation state there must be another basis than pre-political agreement on substantial values and common interests for the justification of rights and policymaking. It has been suggested that the inclusive procedures constituted by the rights of the citizens to participate and hold to account, can bear the burden of legitimation alone. Democracy and human rights, which reflect the core cognitive legitimacy basis of nation states, are held be the only viable normative 
resource basis for a post-national political order. ${ }^{37}$ This refers to the bare bones of the constitutional state's cognitive political principles - rule of law, popular sovereignty and citizenship - in contrast to the pre-political we-feeling and allegiance making up the existential common ground of nation-hood, of love of country.

The Union has not been able to plainly ground its actions on what Europe is or what it is to be a European. As a collective identity in a strong sense is lacking, identification with common concerns can not be taken for granted. Rather it has to be created through the political struggle for recognition and justice. The lack of pre-political identification with the emerging political community can, in principle, be compensated for by a public debate that forms catalytic functions of enlarged citizenship, solidarity, and plural identities. The constitutional development of the EU could make for this contribution as far as it triggered a European wide debate and thus had an identity shaping effect. A profound debate on the constitutional essentials could root the basic principles of government in a European-wide civic culture. Establishing the convention and a proposal for a European Constitution are vital vehicles of such, because these institutions revolve on the basic rules for action coordination and intercultural coexistence. A cross-border constitutional debate depends, however, on a European public sphere that still remains in latency. ${ }^{38}$

\section{Conclusion}

For the first time in human history, we are now witnessing the development of a democratic system that is not based on a conception of a culturally homogenized people, or brought about through war or brute force, but one that has emerged through voluntary cooperation, through bargaining and deliberation and other trust inducing mechanisms. Through this the EU has progressed beyond the initial stage of a purely voluntary association and moved into a supranational legal system based on the precepts of higher law-constitutionalism endowed with an authoritative dispute mechanism. It is an entity equipped with an organized capacity to act and it has now undertaken steps to reduce the democratic deficit. All legal persons and not just states have judicially enforceable rights and legitimacy established through domestic channels, through national democracy, has been supplemented with direct chains of influence. The European Parliament has 
obtained more power and majority vote has replaced unanimity as a decision rule in several policy fields. Consequently, the EU is both a Union of states and of citizens.

The EU is a large scale experiment searching for binding constitutional principles and institutional arrangements beyond the mode of rule entrenched in the nation state. State power is being domesticated by supranational law, and the only legitimacy basis for this law is the constitutional developments in Europe that emerged in the wake of the French revolution, and which for more than 200 years now has contributed massively to the stabilization of nation states. In this tradition constitutions are seen as arrangements for respecting the equality and the autonomy of the individual in the realization of the idea of popular self-government. The European integration process testifies to a promising yet unaccomplished process of democratization that can only be carried through by a more encompassing and comprehensive constitutionalizing process than we have witnessed so far.

\section{Notes}

1 L.C. Blichner and A. Molander, 'What is juridifcation?', ARENA Working Paper 14/2005 (Oslo: ARENA, 2005).

2 J. Bohman, 'Reflexive constitution-making and transnational governance', in ed. E.O. Eriksen, Making the European Polity: Reflexive Integration in the EU (London: Routledge, 2005), p. 39.

${ }^{3} \mathrm{~B}$. Zangl, 'The rule of law: internationalization and privatization. Is there an emerging international rule of law?’ European Review, Vol. 13. Supp. No. 173-91. (2005) p.73

4 R.O. Kehoane, A. Moravcsik and A. Slaugther (2002) 'Legalized dispute resolution: Interstate and transnational.’ International Organization 54(3): (457-488)

${ }^{5}$ H. Brunkhorst, ‘Menschenrechte und Souveränität - ein Dilemma?’, in eds. H. Brunkhorst, W.R. Köhler and M. Lutz-Bachman, Recht auf Menschenrechte (Frankfurt: Suhrkamp, 1999); O. Höffe, Demokratie im Zeitalter der Globalisierung (München: C.H. Beck, 1999); D. Held, 'Law of States, Law of Peoples: Three Models of Sovereignty’, Legal Theory 8 (2002): 1-44; N. Luhmann, Das Recht der Gesellschaft (Frankfurt: Suhrkamp, 1983); B. Fassbender, 'The United Nations Charter As Constitution of the International Community’, Columbia Journal of Transnational Law 36 (1998): 529-613.

6 See J. Habermas, ‘The War in Kosovo - Cosmopolitical Lessons’, Constellations, 6(3) (1999): 263-72; J. Habersmas Der gespaltene Westen. (Frankfurt: Suhrkamp, 2004). See further K.O. Apel, 'On the Relationship Between Ethics, International Law and the Politico-Military Strategy in Our Time’, European Journal of Social Theory 4(1) (2001): 29-39; eds. J. Bohman, and M. Lutz-Bachmann, Perpetual Peace. Essays on Kant's Cosmopolitan Ideal (Cambridge, Mass.: The MIT Press, 1997).

7 J.H. Morgenthau, Politics among Nations (New York: McGraw-Hill., 1978), p. 321.

8 A more secure world: our shared responsibility. Report of thre Secretary-General's High-level Panel on Threats, Challenges and Change (New York: UN, 2004), p. 17.

${ }^{9}$ Denationalisation, which is a less demanding concept than globalisation, denotes the relative increase of cross-national transactions (compared to national exchanges) and the extension of social spaces beyond 
national control (M. Zürn, 'The state in the post-national constellation - societal de-nationalization and multi-level governance’, ARENA Working Paper 35/1999 (Oslo: ARENA, 1999), p. 7.

${ }^{10}$ D. Held, Democracy and the Global Order. From the Modern State to Cosmopolitan Governance (Stanford: Stanford University Press, 1995), p. 16.

${ }^{11}$ N. Bobbio, 'Democracy and the International System', in eds. D. Archibugi and D. Held, Cosmopolitan Democracy: An Agenda for a New World Order (Cambridge: Polity, 1995).

${ }^{12} \mathrm{~J}$. Habermas, The Inclusion of the Other: Studies in Political Theory (Cambridge, MA: MIT Press, 1998), p. 169.

${ }^{13}$ The EU's track record in sustaining peace and creating stability and wealth is outstanding. See e.g. F. Schimmelfenning and V. Sedelmeier, eds., The Europeanisation of Central and Eastern Europe (Cornell University Press, 2005).

${ }^{14}$ See the leading cases 26/62 Van Gend en Loos and 6/64 Costa. On the supranational character of EC law, see J. H.H.Weiler The Constitution of Europe. (Cambridge: Cambridge University Press, 1999); K. Alter Establishing the Supremacy of European Law , (Oxford, Oxford University Press 2001); A. Stone Sweet, The Judicial Construction of Europe, (Oxford: Oxford University Press, 2004).

${ }^{15}$ It was supranational from the very inception. "Later the supranational authority of the EC Commission was downgraded, but, nevertheless, the Community institutions constitute political agency and enjoy a considerable degree of political autonomy” B.Kohler-Koch 'European governance and system integration', in eds. E.O. Eriksen, C. Joerges, and F. Rödl, Law and Democracy in the Post-national Union. Arena Report No 1/2006, p. 94

${ }^{16}$ G. Frankenberg, 'The Return of the Contract: Problems and Pitfalls of European Constitutionalism', European Law Journal 6(3) (2000): 257-76, pp. 260-1.

${ }^{17}$ This states that only decisions that no one will find unprofitable or that will make parties worse off, if not accomplished, will be produced, and hence lend legitimacy to international negotiations (Scharpf 1999: 237).

${ }^{18}$ See E.O. Eriksen, J.E. Fossum and A.J. Menéndez, eds, The Chartering of Europe: The Charter of Fundamental Rights and its Constitutional Implications (Baden Baden: Nomos: 2003). S. Peers and A. Ward (ed.), The EU Charter of Fundamental Rights (Oxford: Hart Publishers, 2004), T. Hervey and J. Kenner (eds.), Economic and Social Rights under the EU Charter (Oxford: Hart Publishers: 2003)

${ }^{19}$ J. Schönlau, Drafting the EU Charter. (Basingstoke: Palgrave Macmillan) J. Schönlau, 'New Values for Europe? Deliberation, Compromise, and Coercion in Drafting the Preamble to the EU Charter of Fundamental Rights' and D. Tarschys, 'Goal Congestion. Multi-Purpose Governance in the European Union', both in Eriksen et al., The Chartering of Europe; A. Maurer, 'Less Bargaining - More Deliberation: The Convention Method for Enhancing EU Democracy', Internationale Politik und Gesellschaft 1 (2003): 167-190.

${ }^{20}$ See E.O. Eriksen, J.E. Fossum and A.J. Menéndez, eds, Developing a Constitution for Europe (London: Routledge, 2004), especially the chapters by Closa, Fossum and Magnette.

${ }^{21}$ A. J. Menéndez, “"Rights to Solidarity” Balancing Solidarity and Economic Freedoms', in eds. E.O. Eriksen, J.E. Fossum and A.J. Menéndez, The Chartering Of Europe (Baden Baden: Nomos, 2003), p. 192. .${ }^{22}$ K. Lenaerts and E. de Smitjer, 'A "Bill of Rights" for the European Union', Common Market Law Review 38 (2001): 273-300, pp. 298-99

${ }^{23}$ The Charter ' $(\ldots)$ is a legally enforceable text which underlines the importance of the rule of law in the $\mathrm{EU}$ and it is the ultimate proof of the focal role that EU citizens have come to play in the European integration process' (ibid. 300).

24 Among others, Case T-54/99, max.mobil Telecommunications Service GmbH v. Commission, Judgment of 2 May 2001, not yet reported, par 48 and Case T-211/02, Tideland Signal Limited/Comisión, Judgment of 27 September 2002, not yet reported, par. 37Case T-77/01, Territorio Histórico de Álava Diputación Foral de Álava, Territorio Histórico de Bizkaia - Diputación Foral de Bizkaia, Territorio Histórico de Gipuzkoa - Diputación Foral de Gipuzkoa y Juntas Generales de Gipuzkoa, Comunidad autónoma del País Vasco - Gobierno Vasco contre Commission des Communautés européennes, Judgment of 11 January 2002, not yet reported. See par. 35.

25 Advocate-General Mischo in Joined Cases C-20/00 and C-64/00, Booker Aquaculture Ltd. Cited from Brand: 2002: 401-402. 
26 See P. Pescatore, 'The Doctrine of "Direct Effect”: An Infant Disease of Community Law', European Law Review 8 (1983): 155-157; E. Stein, 'Lawyers, Judges and the Making of a Transnational Constitution', American Journal of International Law 75(1) (1981): 1-27; G.F. Mancini, 'The Making of a Constitution for Europe', Common Market Law Review 26(4) (1989): 595-614; M. Kumm, 'Constitutional Supremacy and the Constitutional Treaty’, European Law Journal 11(3( (2005): 262-307, p 289.

${ }^{27}$ Kelsen, H. (1944) Peace through Law. Chapel Hill: University of North Carolina. 28 P. Magnette, 'Deliberation or bargaining? Coping with constitutional conflicts in the Convention on the Future of Europe', in eds. E.O. Eriksen, J.E. Fossum and A.J. Menéndez, Developing a Constitution for Europe (London: Routledge, 2004).

29 On this see A.J. Menéndez, 'Between Laeken and the Deep Blue Sea - An Assessment of the Draft Constitutional Treaty from a Deliberative-Democratic Standpoint', European Public Law 11 (1) (2005): 105-144.

30 J.E. Fossum and A.J. Menéndez, ‘The Constitution's gift? A deliberative democratic analysis of constitution making in the European Union', European Law Journal 11(4) (2005): 380-410.

31 See R Bourguignon-Wittke, E. Grabitz, O.Schmuck, S. Steppat, W. Wessels, 'Five Years of the Directly Elected European Parliament: Performances and Prospects', Journal of Common Market Studies 24 (1985): 39-59.

${ }^{32}$ B. Rittberger, Building Europe’s Parliament (Oxford: Oxford University Press, 2005), p. 177.

33 “...parliament without a demos is conceptually impossible, practically despotic.” J.H.H. Weiler, U. Haltern and F. Mayer, 'European Democracy and its Critique', in ed. J. Hayward, The Crisis of Representation in Europe (London: Frank Cass, 1995), p. 4. See further R. Bellamy and D. Castiglione, 'The uses of democracy: reflections on the European democratic deficit', in eds. E.O. Eriksen and J.E. Fossum, Democracy in the European Union: Integration Through Deliberation? (London: Routledge, 2000); J. Bohman, 'Reflexive Constitution-making' and B. Peters, 'Public Discourse, Identity and the Problem of Democratic Legitimacy', in ed. E.O. Eriksen, Making the European Polity.

${ }^{34}$ See D. Grimm 'Treaty or Constitution? The legal basis of the European Union after Maastricht.' In E. O. Eriksen, J. E. Fossum and A. G. Meneéndez (eds) Develolping a Constitution for Europe (London:

Routledge, 2004)

${ }^{35}$ C. Offe, '”Homogeneity” and Constitutional Democracy: Coping with Identity Conflicts through Group Rights', Journal of Political Philosophy 5(2) (1998): 163-82; D. Miller, On Nationality (Oxford: Oxford University Press, 1995).

${ }^{36} \mathrm{~J}$. Habermas, The Inclusion of the Other, p 161

${ }^{37}$ J. Habermas, The Postnational Constellation. Political Essays (Cambridge: Polity Press, 2001), 113ff.

${ }^{38}$ B. Peters, "Public discourse, identity and the problem of democratic legitimacy", in E.O.Eriksen (ed.) Making the European Polity, Reflexive Integration in the EU. (London: Routledge, 2005) 